\title{
1.4 Аналіз природних джерел питного водопостачання України
}

Беззаперечним є той факт, що вода - це один із небагатьох елементів, без якого існування життя немислиме. Поряд 3 тим завданням урядів країн $\epsilon$ забезпечення якісною водою для життєдіяльності, а також безперебійна та доступна і безпечна подача води до усіх споживачів. Саме тому доступ до якісної питної води це основа здоров’я населення міста, країни, регіону чи планети загалом. Така вода не становить ніякого ризику для людського здоров'я при іiі споживанні, а навпаки, є джерелом забезпечення необхідними мікро та макроелементами.

Залежно від країни та регіону стандарти питної води можуть відрізнятися значною мірою[61, 62]. Сдиного шляху, який прийнятний по всьому світу, не існує. В процесі розроблення та використання стандартів необхідно зважати на, не лише існуюче водне законодавство, але й яке воно буде у перспективі; на стан та якість охорони здоров'я. Важливо, щоб кожна із сучасних країн проаналізували свої потреби (в першу чергу) і оцінили можливості в тому, що стосується розроблення законодавчої системи регулювання. Реальна оцінка безпеки життя та діяльності - це питання, при вирішенні якого, свою показову роль має відіграти все суспільство загалом, і кожен громадянин окремо. Значну роль у впливі на дане питання необхідно віддати зміні клімату, що проявляється в зміні тривалості та інтенсивності як посухи так і кількості опадів. I в першому та другому випадку це значною мірою впливає на якість, і кількість води. Тому 3 метою зменшення негативного впливу на водопостачання необхідно проводити відповідні планувальні і управлінські рішення.

Поряд зі зміною клімату також потрібно розглядати демографічні зміни, в тому числі такі як постійна, асиміляція-зростання міст. Збільшення кількості міського населення створює істотні проблеми для забезпечення якісної питної води.

Безпека питного водопостачання - це насамперед забезпечення якісного, безперебійного шляху від водозбору до споживача води, першочерговою метою 
якої є попередження забруднення питної води або ж хоча б зменшення кількості забруднення до рівня, який $є$ не шкідливим для здоров'я людини[63,64].

За міжнародними стандартами Україна належить до країн 3 малим забезпеченням водою на одного жителя населення, що становить менше 1,1 тис. $\mathrm{m}^{3} /$ рік людина. Наша територія характеризується нерівномірним розподілом водних ресурсів. Головною проблемою України, що пов'язана 3 водними ресурсами, зумовлені особливостями формування України, $\epsilon$ незбалансованість розташування підприємств, які споживають найбільше води, а також недосконалість водної політики. Лише 92,7\% видобутої води потрапляє до споживачів[62].

До фізико-географічних чинників, які характеризують ускладнення водноекологічних умов нашої держави, відносять:

- значна площа переважання маловодних степової (40 \%) та лісостепової (34\%) 30н;

- обмеженість водних ресурсів власного формування (50 млрд м $3 /$ рік).

В Україні найбільший об’м води до споживачів потрапляє через поверхневі водозабори. Коротко розглянемо характеристику усіх басейнів стоку великих річок України.

Водоспоживання при використання води із поверхневих джерел України, у басейновому розрізі представлено у таблиці 1.

Басейн річки Дніпро. Дніпро, є основною річковою системою України, водозбір якої охоплює 48 \% площі території держави. Його стік забезпечує до 70 \% питно-господарських потреб. У басейні містяться 33 питних водозаборів. 
Таблиця 1.

Водоспоживання з поверхневих джерел у басейновому розрізі на території України

\begin{tabular}{|l|l|l|}
\hline Басейн стоку & Об’єм, млн. ${ }^{3}$ & Відсоток \\
\hline Дніпра & 7736 & 70.55 \\
\hline Сіверського Дінця & 1266 & 11.54 \\
\hline Південного Бугу & 271,8 & 2.48 \\
\hline Дністра & 464,6 & 4.24 \\
\hline Дунаю & 651,7 & 5.94 \\
\hline Приазов’я & 575,7 & 5.25 \\
\hline Всього & 10965,8 & 100 \\
\hline
\end{tabular}
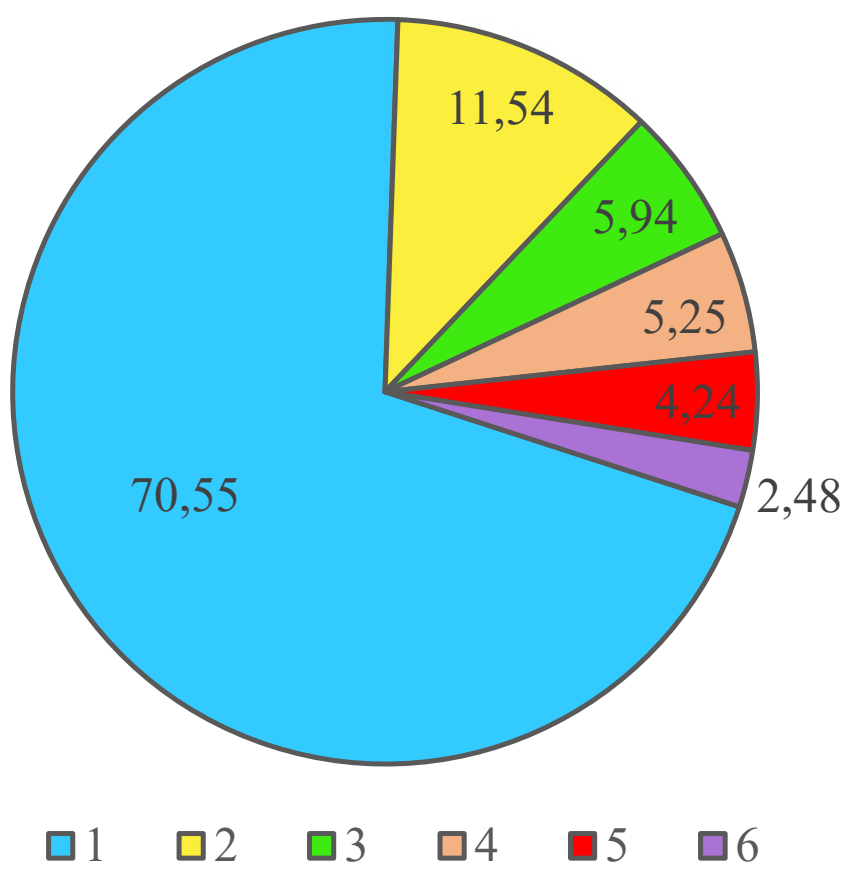

Рисунок 1. Споживання води з поверхневих джерел для водопостачання у відсотка з річок України :1. - р. Дніпро; 2.- р. Сіверський Дінець; 3 - р. Пд Буг; 4 - р. Дністер; 5 - р. Дунай; 6 - р. Приазов’я

Для басейну річки Дніпро характерні регіональні аспекти формування їх якості. Води у верхній течії Дніпра характеризуються підвищеним вмістом природних сполук гумінових та фульво кислот, сполук заліза та марганцю. 
Кольоровість води є індикатором вмісту цих сполук. У зв'язку з цим, найбільше природне (біогенне) забруднення серед усіх водосховищ Дніпровського каскаду спостерігається саме у Київському водосховищі.

Вміст радіонуклідів у водах водосховищ Дніпровського каскаду та річках басейну у межах контрольованої території у цілому був стабільним і значно нижчим за встановлені нормативи.

Басейн річки Дністер. Якісний стан поверхневих вод у місцях водозаборів, що використовуються у басейні річки Дністер, як джерела питного водопостачання, в цілому задовільний. На даній річці знаходиться 14 місць питних водозаборів.

Скиди промислових підприємств м. Калуш значно погіршують показники якісного стану р. Сівка, куди потрапляють зворотні води з високим вмістом солей.

Також значний антропогенний вплив фіксується у пониззі басейну p. Дністер на території Одеської області, після проходження водотоків територією Республіки Молдова. У створах Кучурганського водосховища (с. Граданиці та с. Кучургани), р. Кучурган (с. Степанівка) фіксувалися перевищення за такими показниками: сухий залишок, БСК

Басейн річки Сіверський Дінець. У районі басейну річки Сіверський Дінець існують 3 водозабори, які служать для забезпечення питною водою м. Харків , Луганську, Донецьку та Маріупольську області.

У басейні річки Дунай містяться 11 питних водозаборів. Якісні показники у пробах води, які відбиралися у місцях розташування питних водозаборів у руслових створах р. Дунай задовільний і відповідає вимогам.

На деяких водозаборах відбулося покращення показників за вмістом органічних речовин (БСК, ХСК) та показників солевмісту (сухий залишок, жорсткість, хлориди, сульфати та ін.), а також сполук загального заліза, фосфору.

Така ж картина спостерігалася в усіх створах питних водозаборів суббасейнів Тиси, Пруту та Сірету. 
У басейні річки Південний Буг спостереження постійно здійснюють по 42 пунктах моніторингу, з них 12 - у місцях питних водозаборів.

Поверхневі води басейну р. Південний Буг забруднені в основному органічними сполуками. Підвищений вміст яких $\epsilon$ наслідком впливу забруднюючих речовин, які потрапляють у водні об'єкти зі стічними водами підприємств, і впливу органічних сполук природного походження, що надходять у поверхневі води з торфовищ та боліт.

У басейні річок Причорномор'я та Приазов'я у місцях питних водозаборів характерними є високі значення показників сольового складу - сухого залишку, сульфатів та хлоридів внаслідок регіональних аспектів.

Підземні води питної якості, за виключенням грунтових, на сьогоднішній день $є$ одним із найбільш надійним джерелом постачання води. Саме такі води $є$ захищеними від прямого техногенного забруднення. Саме підземні водозабори формують стратегічну базу питного водопостачання населення України. Видобуток води із підземних джерел за областями представлені у таблиці 2, у відсотковому відношенні зображено на рисунку 2.
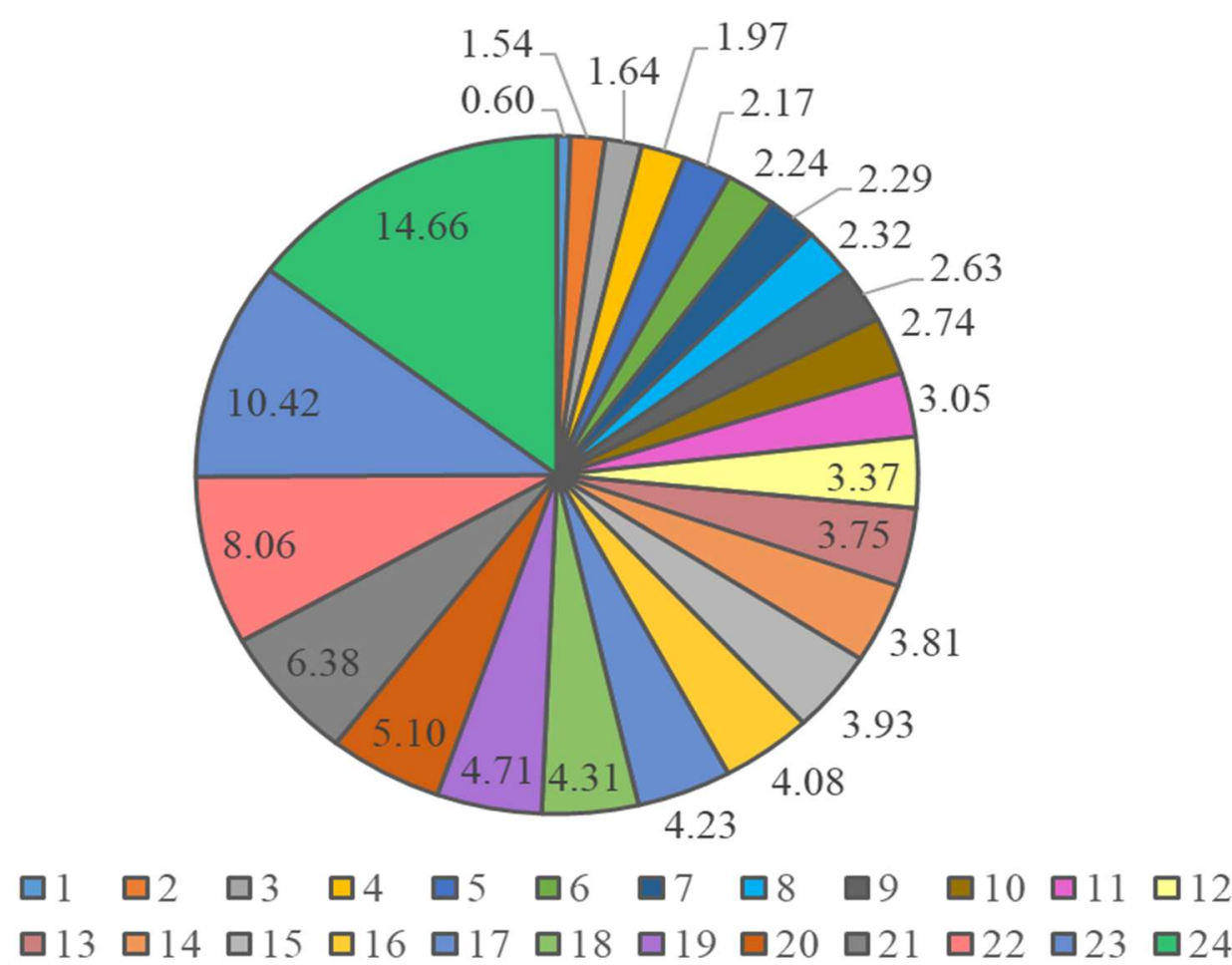

Рисунок 2. Видобуток підземних вод для водопостачання по областях України у відсотках, номери секторів відповідають номерам областей у таблиці 2. 
Таблиця 2.

Видобуток підземних вод для водопостачання по областях України

\begin{tabular}{|c|c|c|c|}
\hline № & Область & тис. $\mathrm{M}^{3}$ & $\%$ \\
\hline 1 & Івано-Франківська & 16.06 & 0.60 \\
\hline 2 & Миколаївська & 41.27 & 1.54 \\
\hline 3 & Вінницька & 43.901 & 1.64 \\
\hline 4 & Кіровоградська & 52.765 & 1.97 \\
\hline 5 & Закарпатська & 57.978 & 2.17 \\
\hline 6 & Житомирська & 59.924 & 2.24 \\
\hline 7 & Харківська & 61.248 & 2.29 \\
\hline 8 & Чернівецька & 62.06 & 2.32 \\
\hline 9 & Тернопільська & 70.377 & 2.63 \\
\hline 10 & Одеська & 73.446 & 2.74 \\
\hline 11 & Запорізька & 81.539 & 3.05 \\
\hline 12 & Сумська & 90.273 & 3.37 \\
\hline 13 & Дніпропетровськ & 100.375 & 3.75 \\
\hline 14 & Полтавська & 101.936 & 3.81 \\
\hline 15 & Чернігівська & 105.293 & 3.93 \\
\hline 16 & Черкаська & 109.217 & 4.08 \\
\hline 17 & Рівненська & 113.186 & 4.23 \\
\hline 18 & Хмельницька & 115.314 & 4.31 \\
\hline 19 & Луганська & 125.997 & 4.71 \\
\hline 20 & Волинська & 136.475 & 5.10 \\
\hline 21 & Херсонська & 170.741 & 6.38 \\
\hline 22 & Київська & 215.622 & 8.06 \\
\hline 23 & Донецька & 278.751 & 10.42 \\
\hline 24 & Львівська & 392.44 & 14.66 \\
\hline \multirow[t]{2}{*}{25} & А.Р. Крим & Н.в & Н.в \\
\hline & Всього & 2676.188 & 100.00 \\
\hline
\end{tabular}

У 2010 році Генеральна Асамблея ООН визнала право людини на якісну воду і забезпечення санітарією кожного мешканця Землі. Згідно наданих даних ООН, у світі є близько 5,2 мільярди людей, які мають доступ до безпечної та недорогої питної води. Поряд з цим 2 мільярди позбавлені такої можливості. 
На світовому рівні питаннями якості води займається Всесвітня організація охорони здоров’я ВООЗ. Саме ця організація визначає, якими повинні бути критерії якості води.

В Україні якість питної води визначається нормами ДСТУ 7525:2014 «Вода питна. Вимоги та методи контролювання якості» [63]. У 2010 році цей документ замінив застарілий ГОСТ. У даному документі визначено 90 бактеріологічних та фізико-хімічних показників, за якими нормується якість води.

Норми представлені у [63] доволі жорстко регулюють якість питної води. Вимоги у ньому значно вищі, ніж це дозволяє ВООЗ. Порівняння вимог, щодо якості питної води представлено у табл.3.

Таблиця 3.

Порівняння якості питної води України та інших держав

\begin{tabular}{|c|c|c|c|c|}
\hline \multirow{2}{*}{$\begin{array}{l}\text { Показник якості } \\
\text { питної води }\end{array}$} & \multirow{2}{*}{$\begin{array}{l}\text { Одиниця } \\
\text { виміру }\end{array}$} & \multicolumn{3}{|c|}{ Гранично допустима концеитрація } \\
\hline & & Україна & Польица & Краӥни $\epsilon C$ \\
\hline 3anax & бал & 2,00 & 3,00 & 3,00 \\
\hline Смак і присмак & бал & 2,00 & 2,00 & 2,00 \\
\hline Кольоровість & Град. & 20,00 & 20,00 & 20,00 \\
\hline Мутність & $\mathrm{Mr} /$ дм $^{3}$ & 1,50 & 5,00 & 5,00 \\
\hline Показник $\mathrm{pH}$ & - & $6,00 . .9,00$ & $6,50 . .8,50$ & $6,50 . .8,50$ \\
\hline Залізо загальне & $\mathrm{Mr} / \mathrm{дM}^{3}$ & 0,30 & 0,50 & 0,30 \\
\hline Твердість загальна & $\mathrm{Mr} / \mathrm{дм}^{3}$ & 350,00 & 500,00 & 500,00 \\
\hline Маргансць & $\mathrm{Mr} / \mathrm{дм}^{3}$ & 0,10 & 0,10 & 0,05 \\
\hline Мідь & $\mathrm{Mr} / \mathrm{дM}^{3}$ & 1,00 & 0,50 & 1,00 \\
\hline Хлориди & $\mathrm{Mr} / \mathrm{дM}^{3}$ & 350,00 & 300,00 & 250,00 \\
\hline Цинк & $\mathrm{Mr} / \mathrm{дм}^{3}$ & 5,00 & 5,00 & $0,10-3,00$ \\
\hline Алюміній залишковий & $\mathrm{Mr} / \mathrm{дм}^{3}$ & 0,50 & 0,30 & 0,20 \\
\hline Азот амонійний & $\mathrm{Mr} / \mathrm{дм}^{3}$ & 0,50 & 0,50 & 2,00 \\
\hline Нітрати & $\mathrm{Mr} / \mathrm{дM}^{3}$ & 20,00 & 10,00 & 10,00 \\
\hline Свинець & $\mathrm{Mr} / \mathrm{дм}^{3}$ & 0,03 & 0,05 & 0,05 \\
\hline Фrop & $\mathrm{Mr} / \mathrm{дM}^{3}$ & $0,70-1,5$ & $0,30-1,50$ & $0,70-1,50$ \\
\hline
\end{tabular}

У даній роботі вивчено розподіл питної води 3 природніх джерел. За міжнародними стандартами Україна належить до країн з малим забезпеченням водою на одного жителя населення, що становить менше 1,1 тис. м3/рік людина. Представлено водоспоживання при використання води із поверхневих джерел 
України, у басейновому розрізі (максимально використовують воду з річок басейну Дніпра - 70,55\%, мінімально з річок Приазовя - 2,48\%); із підземних джерел в розрізі по областях України (максимально використовують воду 3 підземних джерел Львіська обл. - 14,66\%, мінімально з Івано-Франківська обл. 0,6\%). Міжнародні організації визнають право людини на якісну воду i забезпечення санітарією кожного мешканця Землі, завданням кожного уряду окремоїни забезпечити населення своєї держави якісною безпечною питною водою. 